UDC 614.7: 616-01/-099

DOI: $10.21668 /$ health.risk/2018.4.07.eng

\title{
HYGIENIC ASSESSMENT OF ENVIRONMENTAL FACTORS THAT CAUSE INSUFFICIENT PROVISION WITH VITAMINS AMONG PRE-SCHOOL CHILDREN
}

\author{
A.M. Yambulatov ${ }^{1}$, O.Yu. Ustinova ${ }^{2,3}$ \\ ${ }^{1}$ Federal Service for Surveillance over Consumer Rights Protection and Human Well-being, Perm Regional Office, \\ 50 Kuybyisheva Str., Perm, 614016, Russian Federation \\ ${ }^{2}$ Federal Scientific Center for Medical and Preventive Health Risk Management Technologies, 82 Monastyrskaya Str., \\ Perm, 614045, Russian Federation \\ ${ }^{3}$ Perm State University, 15 Bukireva Str., Perm, 614990, Russian Federation
}

An issue related to insufficient provision with vitamins among children in Russia requires profound examination, especially as regards reasons for it, as it will allow to work out targeted prevention measures. Our research goal was to perform hygienic assessment of environmental factors (organization of nutrition, chemical contamination of environmental objects) that influence provision of preschool children with vitamins. We chose the following research objects: a typical pre-school children facility located in a large industrial center and 188 children aged 6-7 who attended it. We applied a set of sanitary-hygienic, laboratory, and mathematical techniques in our research. We assessed organization of nutrition in the facility; performed a comparative analysis of nutrition quality with calculation and individual weighting technique. We also examined concentrations of technogenic chemicals in the atmospheric air, the air inside the facility, and water supplied to the facility; determined their concentrations in children's blood; studied antioxidant protection system in children and a level of their provision with vitamins. We detected that nutrition in the facility was imbalanced, and actual consumption of some food products was up to 1.7 times lower that it was suggested in a menu, and actual introduction of vitamins was by $30 \%$ lower than calculated one. We showed that environmental objects (the atmospheric air, indoor air, and drinking water supplied to the facility) on industrially developed territories were contaminated with technogenic chemicals (formaldehyde, phenol, ethylbenzene, chloroform, and residual free/fixed chlorine) and it led to occurrence of their increased concentrations and increased concentrations of their metabolites in children's blood. We proved that increased concentrations of oxygen-containing aldehydes, aromatic hydrocarbons, and chlorine-organic compounds in children's blood made antioxidant protection enzymes less active and caused lower concentrations of antioxidant-active vitamins. So, insufficient provision with vitamins among pre-school children who attend a preschool children facility in a large industrial center is caused not only by insufficient exogenous introduction of vitamins with food but also by effects of their metabolic absorption related to occurrence of technogenic chemicals with pro-oxidant effects in biological media.

Key words: children, pre-school children facilities, hygienic assessment, nutrition, vitamins, rations and nutrition quality, technogenic chemicals.

Introduction. Rational and balanced nutrition makes for optimal metabolism necessary for proper physical and mental development of children while vitamins and microelements deficiency in daily ration leads to 1.5-3.0 times increase in probability of chronic diseases development even at an early age $^{1}[1-3]$. Research performed in the Russian Federation in 2000-2015 revealed that there was an urgent issue related to improper provision with vitamins among more than $70 \%$ of children regardless of a season, age, or a place where a child lived $[1,4,5]$. Insuf- ficient provision with vitamins (primarily A, C, D and B group) was close to hypovitaminosis in some cases; its frequency reached $90 \%$ in some Russian regions and this disorder had a complex nature in $2 / 3$ of children $[6,7]$. It was detected that frequency of insufficient provision with vitamins among children was often equal to $70 \%$ and more on industrially developed territories in spite of better social and economic conditions and higher living standards there $[6,8-10]$.

Most experts consider insufficient provision with vitamins among children to be caused

(C) Yambulatov A.M., Ustinova O.Yu., 2018

Aleksandr M. Yambulatov - chief specialist of the Department for Supervision of Food Hygiene (e-mail: random799@mail.ru; tel.: +7 (342) 236-32-64; ORCID: http://orcid.org/0000-0002-4098-5583).

Olga Yu. Ustinova - Doctor of Medicine, Associate Professor, Deputy Director for Healthcare Services; Associate Professor, professor of the Department of human ecology and life safety (e-mail: ustinova@fcrisk.ru; tel.: +7 (342) 236-32-64; ORCID: http://orcid.org/0000-0002-9916-5491).

${ }^{1}$ Polyakova A.S. Assessment of nutritional status among primary school children and substantiation of activities required to optimize it: thesis of a dissertation for Candidate of Medical Sciences degree. - N. Novgorod, 2005. - 24 p. 
by non-rational nutrition structure, storage procedures and processing technologies applied in food manufacturing, and with low natural concentrations of vitamins in products as well $[11,12]$. It was detected that at present a daily ration, even balanced and variable one, still had most vitamins in quantities that were 20-30\% lower than physiological standards $[5,6,13,14]$. Results of multi-focused research on actual nutrition offered to children at preschool children facilities revealed that it was frequently imbalanced, rations had excessive caloric values, but there was not sufficient quantity of proteins in them as they predominantly contained carbohydrates; fresh fruit, meat, and fermented milk products were also in deficiency [4, 5]. Experts analyzed nutrition consumed by pre-school children at their homes and revealed that nutrition regimes were often violated and children often ate food that was not recommended for children nutrition (culinary products fried in deep fat, chips, snacks, and carbonated drinks) [15-17]. Such "western" food doesn't provide physiological balance of nutrients consumed with it, including vitamins, and, consequently, causes health disorders among children $[5,6,18]$.

At the same time, chemical environmental factors also exert significant influence on children provision with vitamins $[10,19,20]$. Chronic introduction of technogenic chemicals into a child's body causes elevated concentrations of toxicants in biological media accompanied with a significant increase in activity of free radical oxidation processes and, consequently, with greater consumption of vitamins participating in antioxidant protection $[5,15$, 18]. Most experts believe that technogenic chemicals produce the most adverse effects on concentrations of retinol and its ethers, riboflavin, pyridoxine hydrochloride, pantothenic, ascorbic, and folic acids, cholecalciferol, ergocalciferol, and rutin $[2,5,6,11]$.
Our research goal was to perform hygienic assessment of environmental factors (organization of nutrition and chemical contamination of environmental objects) that influence provision with vitamins among pre-school children.

\section{Data and methods.}

We chose the following research object: a typical pre-school children facility located in a large industrial center and 188 children aged 6-7 who attended it. To perform the research, we applied a set of sanitary-hygienic, laboratory, and mathematical techniques. Medical and biological research was accomplished in full conformity with ethical principles fixed in Helsinki Declaration approved in 1975 and last supplemented in 1983 and the RF National Standard GOST-R 52379-2005 2 .

To perform sanitary-hygienic assessment of nutrition in the pre-school children facility, we took data collected during scheduled inspections accomplished by Rospotrebnadzor Regional office in Perm in 2016-2017. We examined nutrition quality and how well it was provided with vitamins via calculations that were based on data taken from menus, technological charts, and rejection logs. We assessed actual nutrition consumed by 120 children at the pres-school children facility with an individual weight method [11].

To study influence exerted by chemical environmental factors on violations of provision with vitamins, we performed a profound laboratory examination of 188 children who had been attending the pres-school facility for not less than 3 years.

Atmospheric air samples were taken on the territory of the pre-school children facility and inside it in conformity with the existing regulatory documents ${ }^{3}$. Formaldehyde was detected in air samples via high-performance liquid chromatography ("Agilent 1200 Series" liquid chromatograph with diode-matrix detector); ethylbenzene was detected via gas chromatography ("Kristall 5000" gas chromatograph with

\footnotetext{
${ }^{2}$ GOST R 52379-2005. Good clinical practice: The RF National Standard. (ICH E6 GCP) [web-source] // KODEKS: an electronic fund of legal and reference documentation. - URL: http://docs.cntd.ru/document/1200041147 (date of visit August 16, 2018).

${ }^{3}$ GOST (State Standard) 17.2.3.01-86. Environmental protection. Atmosphere. Rules for control over air in settlements [web-source] // Gost.one. - URL: https://dev.gost.one/document/GOST_17230186-57912 (date of visit August 16, 2018).

GOST (State Standard) R ISO 16000-1-2007. Air in closed rooms. Part 1. Sampling. General provisions: The RF National Standard [web-source] // KODEKS: an electronic fund of legal and reference documentation. - URL: http://docs.cntd.ru/document/gost-r-iso-16000-1-2007 (date of visit August 16, 2018).
} 
HP-FFAP $50 * 0.32 * 0.50$ capillary column and flame ionization detector); phenol was detected via spectrophotometry ("Lambda" spectrophotometer, "PerkinElmer" Inc., the USA), in conformity with existing methodical and regulatory documents ${ }^{4}$. Average daily concentrations of chemicals were calculated as arithmetic mean of single concentrations in samples taken within one day. Drinking water quality in the pre-school children facility was estimated as per data collected during monitoring by the Federal Information Fund for Social and Hygienic Monitoring and field observation results. Chloroform and tetrachloromethane were detected via gas chromatography ("Chromatek-Kristall-5000" chromatograph with halogen-selective detector) ${ }^{5}$.

Concentrations of vitamins $\mathrm{B}_{6}$ and $\mathrm{B}_{12}$ in children's blood were detected with a microbiologic test combined with a colorimetric technique ("ID-Vit ${ }^{\circledR}$ Vitamin $B_{6}$ " and "ID-Vit ${ }^{\circledR} V i$ tamin $B_{12}$ ", Immunodiagnostik AG, Germany); concentration of vitamin $\mathrm{C}$ was detected with a colorimetric technique with a test system for detecting water-soluble vitamin $\mathrm{C}$ (Immunodiagnostik AG, Germany); concentrations of vitamins $\mathrm{A}, \mathrm{D}$ and $\mathrm{E}$ were detected with ELISA techniques ("Vitamin A, ELISA/Human Vitamin A, VA Elisa Kit, 96 CSB", CUSABIO BIOTECH, Co. Ltd., China; "25-OH vitamin D", "Euroimmune AG" Germany; "Vitamin E, ELISA/Human Vitamin E, VE Elisa Kit, 96 CSB", CUSABIO BIOTECH, Co. Ltd., China) ("ELx808IU" laboratory immunologic analyzer, "Infinite F50" ELISA microplate reader).

To assess strain that occurred in oxidativeantioxidant reactions in examined children, we determined overall antioxidant activity of blood serum, lipid hydroperoxides and malonic dialdehyde concentrations, superoxide dismutase and glutathione peroxidase ("Konelab" automatic biochemical analyzer, "ELx808" ELISA absorbance microplate reader). Research was performed as per conventional procedures with standard test kits.

All the obtained data were analyzed with variation and frequency analysis taking into account Pierson criterion; numerical values validity was estimated as per Fischer and Student criteria; "technogenic chemicals concentration in blood - vitamin contents in blood" relationship and "vitamin concentration in blood - adverse effect marker" relationship were estimated as per odds ratio (OR) calculation and its confidence interval (CI). OR $\geq 1$ meant a correlation existed.

Our research was performed within the plan of scientific-research work approved by the Federal Scientific Center for Medical and Preventive Health Risk Management Technologies in accordance with the branch scientific-research program by Rospotrebnadzor entitled "Hygienic scientific substantiation for minimizing heath risks for the RF population" for 2016-2020.

Results and discussion. According to the data obtained during scheduled inspections, the kitchen unit at the examined pre-school children facility can't facilitate the complete cooking processes and operates with semicooked food; nevertheless, it is equipped with all the necessary technological, cooling, and washing devices. Children are provided with 5 meals a day (breakfast, brunch, lunch, mid-

\footnotetext{
${ }^{4}$ Determination of adverse substances in biological media: Methodical guidelines. - M.: Rospotrebnadzor's Federal Center for Hygiene and Epidemiology, 2008. - 183 p.

MG 4.1.2110-06. Determining mass concentrations of formaldehyde, acetaldehyde, propionic aldehyde, butyric aldehyde and acetone in urine samples via high-performance liquid chromatography [web-source] // KODEKS: an electronic fund of legal and reference documentation. - URL: http://docs.cntd.ru/document/1200065242 (date of visit August 16, 2018).

MG 4.1.764-99. gas chromatography for quantification of aromatic hydrocarbons (benzene, toluene, ethylbenzene, o,$\mathrm{m}$,-p-xylene) in biological media (urine) [web-source] // KODEKS: an electronic fund of legal and reference documentation. URL: http://docs.cntd.ru/document/1200039011 (date of visit August 16, 2018).

MG 4.1.2108-06. Determining mass concentration of phenol in biological media (blood) via gas chromatography [websource] // KODEKS: an electronic fund of legal and reference documentation. - URL: http://docs.cntd.ru/document/1200065240 (date of visit August 16, 2018).

Guide 52.04.186-89 Guide for control over atmospheric contamination (Parts II and III. Appendices to Part I) [web-source] // KODEKS: an electronic fund of legal and reference documentation. - URL: http://docs.cntd.ru/document/1200037440 (date of visit August 16, 2018).

${ }^{5}$ MG 4.1.2115-06 Determining mass concentrations of chloroform, 1,2-dichloroethane, tetrachloromethane in biological media (blood) via gas chromatography analysis of equilibrium vapor [web-source] // KODEKS: an electronic fund of legal and reference documentation. - URL: http://docs.cntd.ru/document/1200065247 (date of visit August 16, 2018).
} 
afternoon snack, and dinner); breaks between meals don't last longer than 4 hours; there is a draft 10-day menu for children younger than 3 and from 3 to 7 years. Cooked food is enriched with vitamin $\mathrm{C}$ all the year round as it is prescribed by the Hygienic Requirements SER 2.4.1.3049-13 ${ }^{6}$. We examined the results obtained during scheduled inspections at the preschool children facility and analyzed data from daily menus and cumulative lists; our examination revealed that food satisfied all agerelated physiological needs of children in nutrients and energy. Assessment of actual meals provided for children didn't reveal any repeated dishes in 3 days menus and this fact, combined with met requirements to a daily set of products, proved that children were offered diverse ration. But at the same time, we studied quantitative characteristics of a menu and revealed that a set of products offered to chil- dren contained 3 times higher quantities of curds, curd products and fish, 1.4 times higher quantities of juices, fruit and vegetables, and 1.7 times higher quantities of sugar than it was fixed in consumption rates; however, milk and fermented milk products were offered in insufficient quantities (Table 1).

As we analyzed menus, technological charts, and rejection logs, we revealed that the total amount of food consumed by children and contents of basic nutrients and energy in daily ration as well conformed to the existing standards and regulations ${ }^{6}$ fixed for nutrition that should be provided for pre-school children. Our further research on daily ration offered to children in the pre-school children facility showed that protein contents accounted for $14.2 \pm 1.4 \%$ of its caloric value; fats accounted for $30,1 \pm 3.7 \%$; and carbohydrates, for $56.2 \pm$ $\pm 3.8 \%$. The figures met the requirements fixed

Table 1

Weight of products consumed by a child at the pre-school children facility compared with recommended hygienic standards (g/day, gross) ${ }^{6}$

\begin{tabular}{|l|c|c|c|}
\hline \multicolumn{1}{|c|}{$\begin{array}{c}\text { Food product } \\
\text { (group of food products }\end{array}$} & $\begin{array}{c}\text { Weight of products consumed } \\
\text { by a child at the pre-school children } \\
\text { facility (examined menus) }\end{array}$ & $\begin{array}{c}\text { Recommended weight } \\
\text { for daily consumption } \\
\text { by children aged 6-7 }\end{array}$ & $\begin{array}{c}\text { Validity } \\
\text { of discrepancy } \\
(p \leq 0.05)\end{array}$ \\
\hline $\begin{array}{l}\text { Milk and fermented milk } \\
\text { products with mass fraction } \\
\text { of fat not lower than 2.5\% }\end{array}$ & $399.1 \pm 107.8^{*}$ & $450^{*}$ & $\mathbf{0 . 0 4 1}$ \\
\hline $\begin{array}{l}\text { Curds, curd products with } \\
\text { mass fraction of fat not } \\
\text { lower than 5\% }\end{array}$ & $118.0 \pm 32.0^{*}$ & $40^{*}$ & $\mathbf{0 . 0 0 2}$ \\
\hline Sour cream & $18.4 \pm 14.0$ & 11 & 1.0 \\
\hline Meat & $102.8 \pm 74.1$ & 60.5 & 0.16 \\
\hline Rye bread (rye-white bread) & 50.0 & 50 & - \\
\hline White bread or grain bread & 80.0 & 80 & - \\
\hline Cereals and beans & $55.0 \pm 31.5$ & 43 & 0.07 \\
\hline Butter & $21.8 \pm 4.2$ & 21 & 0.28 \\
\hline Vegetable oil & $10.3 \pm 6.0$ & $47^{*}$ & 0.37 \\
\hline Sugar & $55.1 \pm 10.6^{*}$ & 114 & 0.0016 \\
\hline Fresh fruit & $126.3 \pm 59.4$ & $100^{*}$ & $\mathbf{0 . 1 * 1 0 ^ { - 5 }}$ \\
\hline Fruit (vegetable) juices & $135.7 \pm 59.4^{*}$ & $39^{*}$ & $1.71^{*} 10^{-5}$ \\
\hline Fish (fillet) & $86.2 \pm 20.9^{*}$ & 209 & 0.92 \\
\hline Potato & $211.5 \pm 106.1$ & 325 & 0.24 \\
\hline Vegetables and greenery & $278.7 \pm 173.6$ & & \\
\hline
\end{tabular}

${ }^{6}$ SER 2.4.1.3049-13. Sanitary-epidemiologic requirements to facilitating, maintenance, and organization of pre-school children facilities functioning: Sanitary-epidemiologic rules and standards [web-source] // KODEKS: an electronic fund of legal and reference documentation. - URL: http://docs.cntd.ru/document/499023522 (date of visit August 16, 2018). 
by the SER 2.4.1.3049-13 ${ }^{6}$ (where proteins account for $12-15 \%$; fats, for $30-32 \%$, and carbohydrates, for $55-58 \%$, accordingly) ${ }^{7}$ (Table 2 ).

We calculated and analyzed daily rations as regards provision with vitamins and revealed that every day children obtained $0.89 \pm 0.20 \mathrm{mg}$ of vitamin $\mathrm{B}_{1}, 1.0 \pm 0.3 \mathrm{mg}$ of vitamin $\mathrm{B}_{2}$, and $39.9 \pm 12.6 \mathrm{mg}$ of vitamin $\mathrm{C}$; the quantities corresponded to age-related physiological consumption rates $^{7}$ (Table 3 ).

We examined actual nutrition provided for children with an individual weight method and detected that children actually consumed 1.2-1.7 times less milk, meat, butter, and sugar than it was calculated (Table 4).

Actual amount of proteins consumed by a child, taking into account all the food he or she refused to finish up, was equal to only $54.2 \pm 10.4 \mathrm{~g}$; fats, $54.2 \pm 10.2 \mathrm{~g}$; carbohydrates, $205.9 \pm 17.5 \mathrm{~g}$; all the figures were on average by $17.5 \%$ lower than values obtained during analysis of menus when the same amounts were calculated theoretically. Simultaneously, actual amount of proteins consumed by children didn't have any authentic discrepancies from physiological standards (54 g; $p=0.27$ ), but consumption of fats and carbohydrates was authentically lower (60 g and $261 \mathrm{~g}$ respectively; $p=0.04-0.001$ ). caloric value of actually consumed ration amounted to only 1,522.8 \pm $\pm 111.9 \mathrm{kcal}$ and it was 1.2 times lower that a value obtained during analysis of menus when it was calculated theoretically $(p \leq 0.001)$ and authentically lower than the recommended hygienic standard (1,800 kcal; $p \leq 0.001)$ (Table 5).

The detected discrepancies between calculated and actual amounts are basically caused by children not finishing all the offered dishes up; losses of nutrients (carbohydrates and fats) and lower caloric value of ration, taking into account actual amounts consumed by children, reach $18.5 \%(p \leq 0.001)$. And as children tended to consume less fats and carbohydrates, a contribution made by these nutrients into overall caloric value of ration also decreased $(32.0 \pm 4.7 \%$ and $54.3 \pm 5.1 \%$ respectively). Simultaneously we detected poorer provision of children's nutrition with certain vitamins and microelements; thus, actual consumption of vitamins $\mathrm{B}_{1}$ and $\mathrm{B}_{2}$ was 1.2-1.3 times lower than the calculated value; $\mathrm{Fe}$ and $\mathrm{Ca}, 1.2-1.4$ times lower $(p=0.02-$ 0.001 ) which was next to the lower bound of the physiological need in them (Table 6).

Table 2

Comparative analysis of caloric value and nutrients contents in ration provided by the pre-school children facility and physiological needs

\begin{tabular}{|l|c|c|c|}
\hline $\begin{array}{c}\text { Energetic and } \\
\text { nutrient value }\end{array}$ & $\begin{array}{c}\text { Standard physiological needs in energy } \\
\text { and nutrients for children aged 3-711 }\end{array}$ & $\begin{array}{c}\text { Actual } \\
\text { provision }\end{array}$ & $\begin{array}{c}\text { Validity of discrep- } \\
\text { ancy }(p \leq 0.05)\end{array}$ \\
\hline Energy (kcal) & 1,800 & $1,864.0 \pm 134.1$ & 0.87 \\
\hline Protein, g & 54 & $66.3 \pm 9.3$ & 0.89 \\
\hline Fats, $\mathrm{g}$ & 60 & $62.5 \pm 9.8$ & 0.63 \\
\hline Carbohydrates, $\mathrm{g}$ & 261 & $261.3 \pm 19.1$ & 0.94 \\
\hline
\end{tabular}

Table 3

Comparative analysis of vitamins and minerals contents in ration provided by the pre-school children facility and physiological needs

\begin{tabular}{|c|c|c|}
\hline Vitamins and minerals & Analysis of menus, $\mathrm{mg}$ & ${\text { Children's physiological needs, } \mathrm{mg} / \text { day }^{\mathrm{Il}}}$ \\
\hline $\mathrm{B} 1$ & $0.89 \pm 0.2$ & $0.4-1.8 \mathrm{mg} /$ day \\
\hline $\mathrm{B} 2$ & $1.0 \pm 0.3$ & $0.3-1.5 \mathrm{mg} /$ day \\
\hline $\mathrm{C}$ & $39.9 \pm 22.6$ & $30-90 \mathrm{mg} / \mathrm{day}$ \\
\hline $\mathrm{Ca}$ & $784.3 \pm 95.7$ & $400-1200 \mathrm{mg} /$ day \\
\hline $\mathrm{Fe}$ & $15.8 \pm 6.0$ & $4-18 \mathrm{mg} /$ day \\
\hline
\end{tabular}

${ }^{7}$ Chemical structure of food products: Reference book / edited by I.M. Skurikhin, Professor, Corresponding member of the MAI, and V.A. Tutel'yan, Professor, Academician, member of the RAMS. - M.: DeLiprint, 2002. - 236 p. 
Table 4

Actual quantities of basic food products actually consumed by a child against calculated amounts: comparative analysis ( $\mathrm{g} /$ day, gross)

\begin{tabular}{|l|c|c|}
\hline \multicolumn{1}{|c|}{ Food products } & $\begin{array}{c}\text { Amounts calculated } \\
\text { as per menus }\end{array}$ & $\begin{array}{c}\text { Individual weight } \\
\text { method }\end{array}$ \\
\hline $\begin{array}{l}\text { Milk and fermented milk products with mass } \\
\text { fraction of fat not lower than 2.5\% }\end{array}$ & $399.1 \pm 107.8^{*}$ & $236.7 \pm 62.3^{*}$ \\
\hline $\begin{array}{l}\text { Curds, curd products with mass fraction of } \\
\text { fat not lower than 5\% }\end{array}$ & $118.0 \pm 32.0$ & $93.02 \pm 54.8$ \\
\hline Sour cream & $19.0 \pm 13.8$ & $18.8 \pm 14.1$ \\
\hline Meat (without bones) & $102.8 \pm 71.4^{*}$ & $62.8 \pm 55.7^{*}$ \\
\hline Fish (fillet) & $86.2 \pm 20.9$ & $77.2 \pm 19.2$ \\
\hline Potato & $211 \pm 106.1$ & $197.8 \pm 111.5$ \\
\hline Vegetables, greenery & $278.7 \pm 173.6$ & $203.71 \pm 122.8$ \\
\hline Fresh fruit & $126.3 \pm 59.4$ & $104.6 \pm 65.5$ \\
\hline Fruit (vegetable) juices & $135.7 \pm 55.6$ & $126.2 \pm 37.2$ \\
\hline Xлеб pжаной & 50.0 & 69.9 \\
\hline White bread & 80.0 & $41.7 \pm 26.3$ \\
\hline Cereals and beans & $49.5 \pm 34.3$ & $18.4 \pm 4.4^{*}$ \\
\hline Butter & $21.9 \pm 4.2^{*}$ & $8.8 \pm 4.6$ \\
\hline Vegetable oil & $9.8 \pm 6.0$ & $39.1 \pm 7.5^{*}$ \\
\hline Sugar & $55.1 \pm 10.6^{*}$ & \\
\hline
\end{tabular}

Note: $*$ means a discrepancy is statistically authentic $(p<0.05)$.

Table 5

Assessment of nutrients contents and caloric value of ration calculated as per menus and performed with individual weight method: comparative analysis of the results

\begin{tabular}{|l|c|c|c|}
\hline $\begin{array}{c}\text { Nutrient and } \\
\text { energetic value }\end{array}$ & $\begin{array}{c}\text { Calculated } \\
\text { as per menus }\end{array}$ & Weight method & $\begin{array}{c}\text { Validity of discrepancy } \\
(p \leq 0.05)\end{array}$ \\
\hline Proteins, g & $66.3 \pm 9.3^{*}$ & $54.2 \pm 10.4^{*}$ & $\mathbf{0 . 0 0 1}$ \\
\hline Fats, g & $62.5 \pm 9.8^{*}$ & $54.2 \pm 10.2^{*}$ & $\mathbf{0 . 0 0 9}$ \\
\hline Carbohydrates, g & $261.3 \pm 19.1^{*}$ & $205.9 \pm 17.5^{*}$ & $\mathbf{1 . 0 7}^{*} \mathbf{1 0}$ \\
\hline Caloric value, kcal & $1,864.5 \pm 134.1^{-11}$ & $1,522.8 \pm 111.9^{*}$ & $\mathbf{1 . 2 1}^{*} \mathbf{1 0}$ \\
\hline
\end{tabular}

Table 6 We examined children's provision with

Contents of certain vitamins and minerals in mg calculated as per menus and assessed with individual weight method: comparative analysis

\begin{tabular}{|c|c|c|c|}
\hline $\begin{array}{c}\text { Vitamins } \\
\text { and } \\
\text { minerals }\end{array}$ & $\begin{array}{c}\text { Calculated as } \\
\text { per menus }\end{array}$ & $\begin{array}{c}\text { Weight } \\
\text { method }\end{array}$ & $\begin{array}{c}\text { Validity of } \\
\text { discrepancy } \\
(p \leq 0,05)\end{array}$ \\
\hline $\mathrm{B} 1$ & $0.89 \pm 0.2^{*}$ & $0.72 \pm 0.2^{*}$ & $\mathbf{0 . 0 0 0 1}$ \\
\hline $\mathrm{B} 2$ & $1.0 \pm 0.3^{*}$ & $0.79 \pm 0.28^{*}$ & $\mathbf{0 . 0 0 0 1}$ \\
\hline $\mathrm{C}$ & $39.9 \pm 22.6$ & $35.0 \pm 21.8$ & 0.4 \\
\hline $\mathrm{Ca}$ & $784.3 \pm 95.7^{*}$ & $571.2 \pm 64.3^{*}$ & $\mathbf{2 . 0 9 * 1 0 ^ { - 1 0 }}$ \\
\hline $\mathrm{Fe}$ & $15.8 \pm 6.0^{*}$ & $13.5 \pm 6.3^{*}$ & $\mathbf{0 . 0 0 0 5}$ \\
\hline
\end{tabular}
vitamin and revealed that content of vitamin A in blood $\left(0.23 \pm 0.02 \mu \mathrm{g} / \mathrm{cm}^{3}\right)$ on average amounted to the physiological standard $\left(0.13-0,51 \mu \mathrm{g} / \mathrm{cm}^{3} ; p=0.68\right)$; however, it didn't exceed $0.12 \pm 0.01 \mu \mathrm{g} / \mathrm{cm}^{3}$ in $15 \%$ children and it was authentically lower that the standard $(p \leq 0.01)$. Contents of vitamin $\mathrm{E}$ $\left(0.37 \pm 0.03 \mu \mathrm{mol} / \mathrm{dm}^{3}\right)$ corresponded to the physiological standard $\left(0.15-0.87 \mu \mathrm{mol} / \mathrm{dm}^{3}\right.$, $p=0.46-0.87)$ in all examined children. But at the same time, provision with vitamin $\mathrm{C}$ didn't exceed $4.82 \pm 0.31 \mu \mathrm{g} / \mathrm{cm}^{3}$ and was close to the lower bound of the physiological standard (4.0-14.96 $\left.\mu \mathrm{g} / \mathrm{cm}^{3}, p=0.09\right)$; and it amounted 
to only $2.88 \pm 0.23 \mu \mathrm{g} / \mathrm{cm}^{3}$ in $75 \%$ children ( $p \leq 0.001$ against the physiologic standard). Average provision with vitamin $\mathrm{D}$ in the examined children reached $29.38 \pm 1.91 \mathrm{ng} / \mathrm{cm}^{3}$ (the physiological standard is $30-100 \mathrm{ng} / \mathrm{cm}^{3}$, $p=0.26$ ); however, it didn't exceed 23.16 \pm $\pm 1.13 \mathrm{ng} / \mathrm{cm}^{3}$ in $70 \%$ children and was lower than the physiological standard $(p=0.02)$. We revealed the same trend when analyzing contents of vitamins B group: as average group contents of vitamin $\mathrm{B}_{6}$ amounted to $6.48 \pm$ $\pm 0.58 \mu \mathrm{g} / \mathrm{dm}^{3}$ (the physiological standard is $\left.4.6-18.6 \mu \mathrm{g} / \mathrm{dm}^{3}, p=0.72\right) ; 60 \%$ children had only $3.46 \pm 0.20 \mu \mathrm{g} / \mathrm{dm}^{3}$ in their blood which was lower than the standard $(p=0.02)$. Contents of vitamin $\mathrm{B}_{12}$ amounted to only $166.35 \pm 24.49 \mathrm{pmol} / \mathrm{dm}^{3}$ (the standard being $\left.149-616 \mathrm{pmol} / \mathrm{dm}^{3}, p=0.68\right)$, however, it was even lower in $45 \%$ children (121.44 \pm $\pm 4.10 \mathrm{pmol} / \mathrm{dm}^{3}$ ) and didn't correspond to the physiological standard $(p=0.02)$. Overall, only $22.3 \%$ of the examined children had contents of basic vitamins (A, C, Д, E, B 6 и $\left.\mathrm{B}_{12}\right)$ in their blood that corresponded to the physiological standards. Selective deficiency of only one vitamin (basically it was vitamin $\mathrm{B}_{12}$ ) was detected in $37.8 \%$ children; combined deficiency of two vitamins, in $35.1 \%$ $\left(\mathrm{B}_{6}\right.$ and $\mathrm{B}_{12}$ in $28.2 \%$ children, and vitamins $\mathrm{B}_{12}$ and $\mathrm{D}$ in $6.9 \%$ ); a situation when a child had vitamin deficiency as per three vitamins $\left(\mathrm{B}_{6}, \mathrm{~B}_{12}\right.$ and $\left.\mathrm{D}\right)$ was rare and it was detected only in $4.8 \%$ of the examined children.

To establish what role chemical factors played in occurring vitamins deficiency among children, we assessed atmospheric air quality on the territory of the pre-school children facility and inside it. Our research revealed that average daily contents of formaldehyde in the atmospheric air amounted to $0.0051 \pm 0.0010 \mathrm{mg} / \mathrm{m}^{3}$ (MPCa.d. $=0.01 \mathrm{mg} / \mathrm{m}^{3}, p \leq 0.001$ ); ethylbenzene concentration was $\leq 0.002 \mathrm{mg} / \mathrm{m}^{3}$ (MPCa.d. = $\left.=0.02 \mathrm{mg} / \mathrm{m}^{3}, p \leq 0.001\right)$, and it didn't exceed any hygienic standards. However, phenol concentration $\left(0.0074 \pm 0.0018 \mathrm{mg} / \mathrm{m}^{3}\right.$; MPCa.d. $=$ $\left.=0.003 \mathrm{mg} / \mathrm{m}^{3}, p \leq 0.001\right)$ was 2.5 times higher than the permissible one. At the same time, our research revealed that formaldehyde and phenol concentrations in the air in playrooms reached $0.0270 \pm 0.0054 \mathrm{mg} / \mathrm{m}^{3}$ and $0.0169 \pm 0.0042$ $\mathrm{mg} / \mathrm{m}^{3}$ respectively, and it was higher than permissible levels $(p \leq 0.0001-0.001)$. We also detected ethylbenzene in the air inside playrooms $\left(0.0013 \pm 0.0003 \mathrm{mg} / \mathrm{m}^{3}\right)$, however, its concentration was lower than the maximum permissible one (MPCa.d. $=0.02 \mathrm{mg} / \mathrm{m}^{3} ; p=0.0001$ ). Chloroform occurred in water supplied to the pre-school children facility $(0.54 \pm 0.08 \mathrm{mg} / \mathrm{l})$ and its concentration amounted to 2.70 MPC $(p \leq 0.001)$; we also detected residual free/bound chlorine there in concentrations equal to $2.20 / 1.25 \mathrm{MPC}$ $(1.1 \pm 0.4 / 1.5 \pm 0.6 \mathrm{mg} / 1 ; p \leq 0.05)$.

Basing on the results obtained in our research, we divided all the children into two basic groups; out focus group was made up of 146 children with their provision with two or more vitamins being lower that the physiological standard; our reference group was made up of 42 children with their vitamin provision being equal to the physiological standards as per all the examined vitamins. Both groups were comparable as per their gender structure $(p=0.83)$. Our next step was to analyze concentrations of technogenic organic chemicals in blood and compare the results. Chemical and analytical research revealed that chloroform contents $(0.00099 \pm$ $\pm 0.00007 \mathrm{mg} / \mathrm{dm}^{3}$ in the focus group; and $0.00071 \pm 0.00006 \mathrm{mg} / \mathrm{dm}^{3}$ in the reference group) and ethylbenzene $(0.00021 \pm 0.00002$ $0.00013 \pm 0.00002 \mathrm{mg} / \mathrm{dm}^{3}$ accordingly) in children from both groups were authentically higher than the average regional contents $(p \leq 0.001)$, but concentrations of phenol $(0.0088 \pm 0.0012$ $\left.0.0055 \pm 0.0016 \quad \mathrm{mg} / \mathrm{dm}^{3}\right), \quad$ formaldehyde $\left(0.00393 \pm 0.00050-0.00202 \pm 0.00026 \mathrm{mg} / \mathrm{dm}^{3}\right)$ and tetrachloromethane $(0.000043 \pm 0.000005$ $0.000024 \pm 0.000007 \mathrm{mg} / \mathrm{dm}^{3}$ accordingly) were authentically lower $(p=0.03-0.001)$. At the same time, concentrations of the examined organic chemicals were authentically higher in children from the focus group than in those form the reference one $(p \leq 0.0001-0.001)$, and a number of children with concentrations of these chemicals in their blood being higher than the average regional level ( $81 \%$ as per phenol; $38 \%$ formaldehyde; $89 \%$, tetrachloromethane; $37 \%$, ethylbenzene) was 1.4-2.1 times greater than in the reference group $(38 \%, 22 \%, 65 \%, 18 \%$ respectively) ( $p=0.02-0.04)$. Children with insufficient vitamins provision ran 2.2-6.9 times 
higher relative risk of increased concentrations of organic chemicals in blood (phenol, formaldehyde, tetrachloromethane, and ethylbenzene) than children from the reference group $(\mathrm{OR}=$ $=2.18-6.89 ; \quad \mathrm{CI}=1.21-8.44 ; p=0.02-0.04)$. Besides, regression analysis allowed to detect a weak correlation between increased ethylbenzene and tetrachloromethane concentrations in blood and a decrease in vitamin $\mathrm{A}$ contents $\left(R^{2}=0.19-0.26 ; F=16.59-216.88\right.$; $p=0.02-0.04)$; an average correlation between increased formaldehyde and tetrachloromethane concentrations and a decrease in vitamin $\mathrm{B}_{6}$ contents $\left(R^{2}=0.39-0.48 ; \quad F=28.77-381.16\right.$; $p=0.001-0.002)$. We also detected an average correlation between increased phenol and formaldehyde concentrations in blood and lower contents of vitamin A $\left(R^{2}=0.39-0.46\right.$; $F=12.03-78.18 ; \quad p=0.01-0.02)$ and vita$\min \mathrm{C} \quad\left(R^{2}=0.37-0.44 ; \quad F=44.31-109.53\right.$; $p=0.01-0.02)$.

We examined oxidative and antioxidant processes and revealed that antioxidant protection in children from the focus group (glutathione peroxidase was equal to $34.44 \pm 5.29 \mathrm{ng} / \mathrm{cm}^{3}$; and superoxide dismutase, to $44.21 \pm 5.00 \mathrm{ng} / \mathrm{cm}^{3}$ ) was authentically lower than in children from the reference group (glutathione peroxidase was equal to $43.78 \pm 5.61 \mathrm{ng} / \mathrm{cm}^{3}$; and superoxide dismutase, to $59.39 \pm 7.00 \mathrm{ng} / \mathrm{cm}^{3}$, $p=0.001-0.014)$. Besides, antioxidant activity of blood serum amounted to $35.23 \pm 1.33 \%$ in children from the focus group while it was authentically higher in the reference group and amounted to $38.63 \pm 1.04 \%(p=0.01)$. We detected an average correlation between increased phenol, formaldehyde, and ethylbenzene concentrations in blood and a decrease in glutathione peroxidase $\left(R^{2}=0.38-0.41\right.$; $F=27.12-149.36 ; p=0.01-0.02)$ and superoxide dismutase $\left(R^{2}=0.47-0.53 ; F=31.74-238.11\right.$; $p=0.01-0.03$ ). Besides, we revealed a correlation between increased chloroform and tetrachloromethane contents in blood and a decrease in superoxide dismutase $\left(R^{2}=0.37-0.44\right.$; $F=12.98-273.25 ; p=0.001-0.02)$ and antioxidant activity of blood serum $\left(R^{2}=0.29-0.38\right.$; $F=19.09-88.24 ; p=0.01-0.02)$.

\section{Conclusions:}

1. Imbalanced nutrition and losses of nutrients caused by children not finishing their food up and not consuming the whole amount of dishes offered to them by the pre-school children facility lead to $20-30 \%$ decrease in quantity of exogenously introduced vitamins.

2. Environmental objects (atmospheric air, indoor air, drinking water supplied to pre-school children facilities) on industrially developed territories are contaminated with technogenic chemicals (formaldehyde, phenol, ethylbenzene, chloroform, residual free/bound chlorine), and it causes higher concentrations of these chemicals and their metabolites in children's blood.

3 . Increased concentrations of oxygencontaining aldehydes, aromatic hydrocarbons, and chlorine-organic compounds in children's blood make antioxidation enzymes less active and lead to lower contents of vitamins with antioxidant potential.

4. High prevalence of hypovitaminosis among pre-school children on industrially developed territories is caused by insufficient exogenous introduction of vitamins with food and effects of their metabolic absorption associated with increased concentrations of technogenic chemicals with pro-oxidant properties in biological media.

Funding. The research was not granted any sponsor support.

Conflict of interests. The authors state there is no any conflict of interests.

\section{References}

1. Kon' I.Ya. Detskaya (pediatricheskaya) dietologiya (nutritsiologiya): dostizheniya i problem [Children (pediatric) dietology (nutritiology): achievements and problems]. Pediatriya, 2012, vol. 91, no. 3, pp. 59-66 (in Russsian).

2. Kostantin Zh., Kugach V.V. Vitaminy i ikh rol' v organizme [Vitamins and their role in a body]. Vestnik farmatsii, 2006, vol. 32, no. 2, pp. 58-70 (in Russian).

3. Makarova A.Yu., Gorelova Zh.Yu., Sokolova S.B. Pitanie chasto boleyushchikh doshkol'nikov v organizovannykh kollektivakh i doma [Nutrition of pre-school children with poor health 
in pre-school children facilities and at home]. Praktika pediatra, 2010, March, April, pp. 46-51 (in Russian).

4. Kuchma V.R., Chernigov V.V. Monitoring of the modernization of childrens nutrition in educational institutions. Zdorov'e naseleniya $i$ sreda obitaniya, 2012, vol. 233, no. 8, pp. 7-10 (in Russian).

5. Chesnokov L.A., Kuz'micheva N.A., Krasikov S.I., Sharapova N.V., Mikhailova I.V. Some indicators of vitamin and antioxidatic status of inhabitans of region. Zdorov'e naseleniya i sreda obitaniya, 2013, vol. 243, no. 6, pp. 9-11 (in Russian).

6. Vrzhesinskaya O.A., Kodentsova V.M., Starovoitov M.V., Safronova A.I., Abramova T.V., Toboleva M.A., Aleshina I.V., Levchuk L.V. Assessment of vitamin supply in preschoolers. Rossiiskii vestnik perinatologii i pediatrii, 2017, vol. 62, no. 1, pp. 114-120. DOI: 10.21508/1027-4065-2017-62-1-114-120 (in Russian).

7. Ponomarenko, A.Yu. Problemy doshkol'nogo pitaniya v Rossii / A.Yu. Ponomarenko [Issues related to pre-school nutrition in Russia]. Rossiya v izmenyayushchemsya mire: Sbornik nauchnykh statei mezhdunarodnoi konferentsii. Kaliningrad, 2014, pp. 88-91 (in Russian).

8. Barman M., Murray F., Bernardi A.I., Sandberg A.-S., Sandin A. Nutritional impact on Immunological maturation during Childhood in relation to the Environment (NICE): A prospective birth cohort in Northern Sweden. BMJ Open, 2018, vol. 8, no. 10, e022013.

9. Zaitseva N.V., May I.V., Balashov S.Yu. Medical and biologic parameters of the population health state in conditions of inhabitancy complex natural-technogenic pollution. Izvestiya Samarskogo nauchnogo tsentra Rossiiskoi akademii nauk, 2009, vol. 11, no. 1-6, pp. 1144-1148 (in Russian).

10. Kuchma V.R., Milushkina O.Yu., Bokareva N.A., Detkov V.Yu., Fedotov D.M. Hygienic evaluation of the influence of environmental factors on the functional indices of schoolchildren. Gigiena i sanitariya, 2013, no. 5, pp. 91-94 (in Russian).

11. Gromova O.A., Torshin I.Yu., Pronin A.V. Kognitivnyi i neiroplasticheskii potentsial vitamina $\mathrm{D}$ u detei i podrostkov [Cognitive and neuroplastic potential of $\mathrm{D}$ vitamin in children and teenagers]. Farmateka, 2015, no. 6, pp. 15-24 (in Russian).

12. Kleshchina Yu.V., Eliseev Yu.Yu., Pavlov N.N. Specific features of the disturbeds nutrition in children. Zdorov'e naseleniya i sreda obitaniya, 2012, vol. 233, no. 8, pp. $20-22$ (in Russian).

13. Perevalov A.Ya., Lir D.N., Tapeshkina N.V. Hygienic assessment of children`s nutrition in preschool educational institutions. methodological approaches. Zdorov'e sem'i - 21 vek, 2014, vol. 4, no. 4, pp. 174-192 (in Russian).

14. Tapeshkina N.V. The structure of the nourishment of preschoolers during the weekend (short report). Voprosy pitaniya, 2014, vol. 83, no. 2, pp. 64-67 (in Russian).

15. Tkachuk E.A., Tarmaeva I.Yu., Tsyrenzhapova N.A., Boeva A.V. Characteristics of mineral composition of food used in primary schools. Kazanskii meditsinskii zhurnal, 2014, vol. 95, no. 3, pp. 434-438 (in Russian).

16. Kim M.-H., Yeon J.-Y. Status and needs of nutrition education for children's sugars intake reduction in elementary school. Journal of Nutrition and Health, 2018, vol. 51, no. 5, pp. 433-444.

17. Tilles-Tirkkonen T., Nuutinen O., Sinikallio S., Poutanen K., Karhunen L. Theory-informed nutrition education curriculum Tools For Feeling Good promotes healthy eating patterns among fifth grade pupils: cross-sectional study. Journal of Human Nutrition and Dietetics, 2018, vol. 31, no. 5, pp. 647-657.

18. Ivanova I.V., Chernaya N.L., Nikolaev A.G., Senyagina E.I. Specificities and stereotypes of nutrition of present-day schoolchildren in Yaroslavl. Voprosy detskoi dietologii, 2010, no. 1, pp. 25-28 (in Russian).

19. Nefedova L.V., Shvets A.A., Nefedov P.V. O sostoyanii sanitarno-epidemiologicheskogo blagopoluchiya doshkol'nykh obrazovatel'nykh uchrezhdenii g. Krasnodara [On sanitary-epidemiologic well-being of pre-school children facilities in Krasnodar]. Fundamental'nye issledovaniya, 2008, no. 6, pp. 66-67 (in Russian).

20. Semenova N.V., Kun O.A., Denisov A.P., Filippova E.D. Influence of level of sanitary and epidemiologic wellbeing on physical development of the children visiting preschool educational institutions. Mezhdunarodnyi zhurnal prikladnykh i fundamental'nykh issledovanii, 2015, no. 3, pp. 378-381 (in Russian).

Yambulatov A.M., Ustinova O.Yu. Hygienic assessment of environmental factors that cause insufficient provision with vitamins among pre-school children. Health Risk Analysis, 2018, no. 4, pp. 66-74. DOI: 10.21668/health.risk/2018.4.07.eng

Received: 28.10 .2018

Accepted: 14.12 .2018

Published: 30.12.2018 